\title{
Sexual dimorphism in the South American water snake Helicops polylepis (Serpentes: Dipsadidae)
}

\author{
Isla Carol Marialva Camargo, ${ }^{1,2}$ Jackeline Cristina Palma Veras, ${ }^{2}$ Síria Ribeiro, ${ }^{2,3,4}$ Ricardo A. \\ Kawashita-Ribeiro, ${ }^{4}$ Rafael de Fraga, ${ }^{2}$ and Alfredo P. Santos-Jr. ${ }^{1,2,4}$ \\ ${ }^{1}$ Universidade Federal do Oeste do Pará, Instituto de Ciências e Tecnologia das Águas, Programa de Pós-Graduação em \\ Recursos Aquáticos Continentais Amazônicos. Rua Vera Paz s/n, Salé, 68040-255, Santarém, PA, Brazil. E-mail: alphredojr@ \\ hotmail.com. \\ ${ }^{2}$ Universidade Federal do Oeste do Pará, Instituto de Ciências da Educação, Laboratório de Ecologia e Comportamento \\ Animal. Rua Vera Paz s/n, Salé, 68040-255, Santarém, PA, Brazil. E-mail: islamarialva@outlook.com. \\ ${ }^{3}$ Universidade Federal do Oeste do Pará, Instituto de Engenharia e Biociências, Programa de Pós-Graduação em Recursos \\ Naturais da Amazônia. Avenida Mendonça Furtado, 2440, Aldeia, 68040-255, Santarém, PA, Brazil. \\ ${ }^{4}$ Universidade Federal do Oeste do Pará, Instituto de Ciências e Tecnologia das Águas, Programa de Pós-Graduação em \\ Biodiversidade. Rua Vera Paz s/n, Salé, 68040-255, Santarém, PA, Brazil.
}

\begin{abstract}
Sexual dimorphism in the South American water snake Helicops polylepis (Serpentes: Dipsadidae). Sexual selection, fecundity selection and ecological divergence have been the main explanations proposed for the origin and maintenance of sexual dimorphism. In this study we provide evidence of sexual dimorphism in the South American aquatic snake Helicops polylepis, which is mainly determined by body and head sizes. Males have longer tails and more subcaudal scales, and females have larger body and head and more ventral scales. The sexual dimorphism observed in different morphological characters of $H$. polylepis occurs in other species of xenodontine snakes and is interpreted as a consequence of sexual selection pressures. Data on growth rates associated with prey availability and female size-related offspring size are necessary to refine our analyzes and test specific hypotheses about the ecological and evolutionary bases of sexual dimorphism in H. polylepis.
\end{abstract}

Keywords: Fecundity, Hydropsini, sexual selection, Squamata.

\section{Resumo}

Dimorfismosexual na serpenteaquática sul-americana Helicops polylepis (Serpentes: Dipsadidae). A seleção sexual, a seleção de fecundidade e a divergência ecológica têm sido as principais explicações propostas para a origem e a manutenção do dimorfismo sexual. Neste estudo, fornecemos evidências de dimorfismo sexual na serpente aquática sul-americana Helicops polylepis, que é determinado principalmente pelo tamanho do corpo e da cabeça. Os machos apresentam caudas mais longas e maior número de escamas subcaudais, e as fêmeas apresentam maior corpo e cabeça e maior

Received 05 February 2020

Accepted 07 June 2021

Distributed June 2021 
número de escamas ventrais. O dimorfismo sexual observado em diferentes caracteres morfológicos de $H$. polylepis ocorre em outras espécies de serpentes xenodontíneas e é interpretado como consequência de pressões de seleção sexual. Dados sobre as taxas de crescimento associadas à disponibilidade de presas e tamanho da prole relacionado ao tamanho da fêmea são necessários para refinar nossas análises e testar hipóteses específicas sobre as bases ecológicas e evolutivas do dimorfismo sexual em $H$. polylepis.

Palavras-chave: fecundidade, Hydropsini, seleção sexual, Squamata.

\section{Introduction}

Sex-related differences in body morphology have evolved in many invertebrates and vertebrates, and efforts to understand the evolution of sexual dimorphism have mainly focused on adaptive and physiological hypotheses (Andersson 1994). The main hypotheses proposed to explain the evolution of sexual dimorphism are sexual selection (e.g., male ritual combat), fertility selection and ecological divergence (Shine 1989, 1993, 1994, Shetty and Shine 2002). Most studies reporting sexual dimorphism in snakes were based on external morphological characters such as body size (Crews et al. 1984, Shine 1988, Mesquita et al. 2010), head size (Shine and Crews 1988, Shine 1991, King et al. 1999, Luiselli et al. 2002, Giraudo et al. 2014), tail size (Shine et al. 1999), body color (Shine 1993), and shape, size and texture of scales (Avolio 2006). However, sexual dimorphism may be also related to venom composition (Furtado et al. 2006) and morphology of cloacal glands (Thorpe 1989, Kissner et al. 1998). Sex-related differences in these characters are attributed to the reproductive success of the species, in males related to sexual competition, in females to energy storage (Bonnet et al. 1998); competition and niche partitioning (Shine 1991, Luiselli et al. 2002), and to evolutionary pressure in relation to the use of the environment (Shine 1989, Mesquita et al. 2010).

The extent to which males exhibit larger adult body size than females indicates that body size correlates with the intensity of male-male competition (intrassexual selection) or female choice for mates (intersexual selection; Shine 1986). Combat between males is common in snakes where males are larger than females, since reproductive success is size-related, generally providing greater mating opportunities for larger-bodied males (Anderson and Vitt 1990, Almeida-Santos and Salomão 2002, Marques et al. 2009). However, in those species for which females are larger than males, larger females may have a reproductive advantage, since larger females can produce more offspring per breeding season (e.g., Shine 1993, 1994, Balestrin and Di-Bernardo 2005, Pizzato et al. 2007, Mesquita et al. 2010).

The genus Helicops clusters with Hydrops and Pseudoeryx to form the monophyletic tribe Hydropsini, endemic to South America (Zaher et al. 2009). Sexual dimorphism has been found in the genus [e.g., Helicops infrataeniatus Jan, 1865, H. leopardinus (Schlegel, 1837)], usually as larger tail size in males and larger body and head sizes in females (Aguiar and Di-Bernardo 2005, Ávila et al. 2006). Helicops polylepis Günther, 1861 is a viviparous aquatic nocturnal species which feeds mainly on fish and occasionally on amphibians (Teixeira et al. 2017). The species inhabits forest streams and riverbanks, generally using roots and riparian vegetation as shelter and foraging sites (Silva Jr. 1993, Santos-Jr. and Ribeiro 2005). No information on sexual dimorphism has been reported for this species. Herein we present data on sexual dimorphism in meristic and morphometric characters measured in $H$. polylepis, to determine sexual dimorphism in body size and shape. 


\section{Materials and Methods}

\section{Data Collection}

We examined 186 specimens of Helicops polylepis from 11 herpetological collections (Appendix I). Specimens originated from Brazil and Colombia, including most of the Amazon Basin and the northwestern Brazilian Cerrado, from Acre $\left(09^{\circ} 01^{\prime} 30^{\prime \prime} \mathrm{S}, 70^{\circ} 48^{\prime} 64^{\prime \prime} \mathrm{W}\right)$ to the Gurupi River $\left(01^{\circ} 50^{\prime} 06^{\prime \prime} \mathrm{S}, 4^{\circ} 21^{\prime} 11^{\prime \prime} \mathrm{W}\right)$ along the west-east axis, and from Chaves $\left(00^{\circ} 12^{\prime} 06^{\prime \prime}\right.$ S, 49 48'01" W) to Chapada dos Guimarães (Manso River, $15^{\circ} 01^{\prime} 36^{\prime \prime} \mathrm{S}, 5^{\circ} 47^{\prime} 59^{\prime \prime} \mathrm{W}$ ) along the north-south axis (Figure 1).

We used scale counts to quantify sexual dimorphism based on meristic characters. Subcaudal scale counts followed Peters (1964), and ventral scale counts followed Dowling (1951). In addition, we analyzed seven morphometric variables: SVL, snout-vent length (measured from the anterior margin of the rostral scale to the cloacal opening); TL, tail length (measured from the cloacal opening to the tip of the tail); HL, head length (measured from the anterior margin of the rostral scale to the quadro-mandibular joint); $\mathrm{HH}$, head height (greatest height, on the posterior portion of the head); HW, head width (measured at the widest part of the posterior portion of the head, using distal region of the mandible as the reference point); SL, snout length (measured from the anterior margin of the rostral scale to the anterior part of the ocular orbit); EMD, eye-mouth distance (measured from the lower edge of the eye socket to the mouth opening). We used

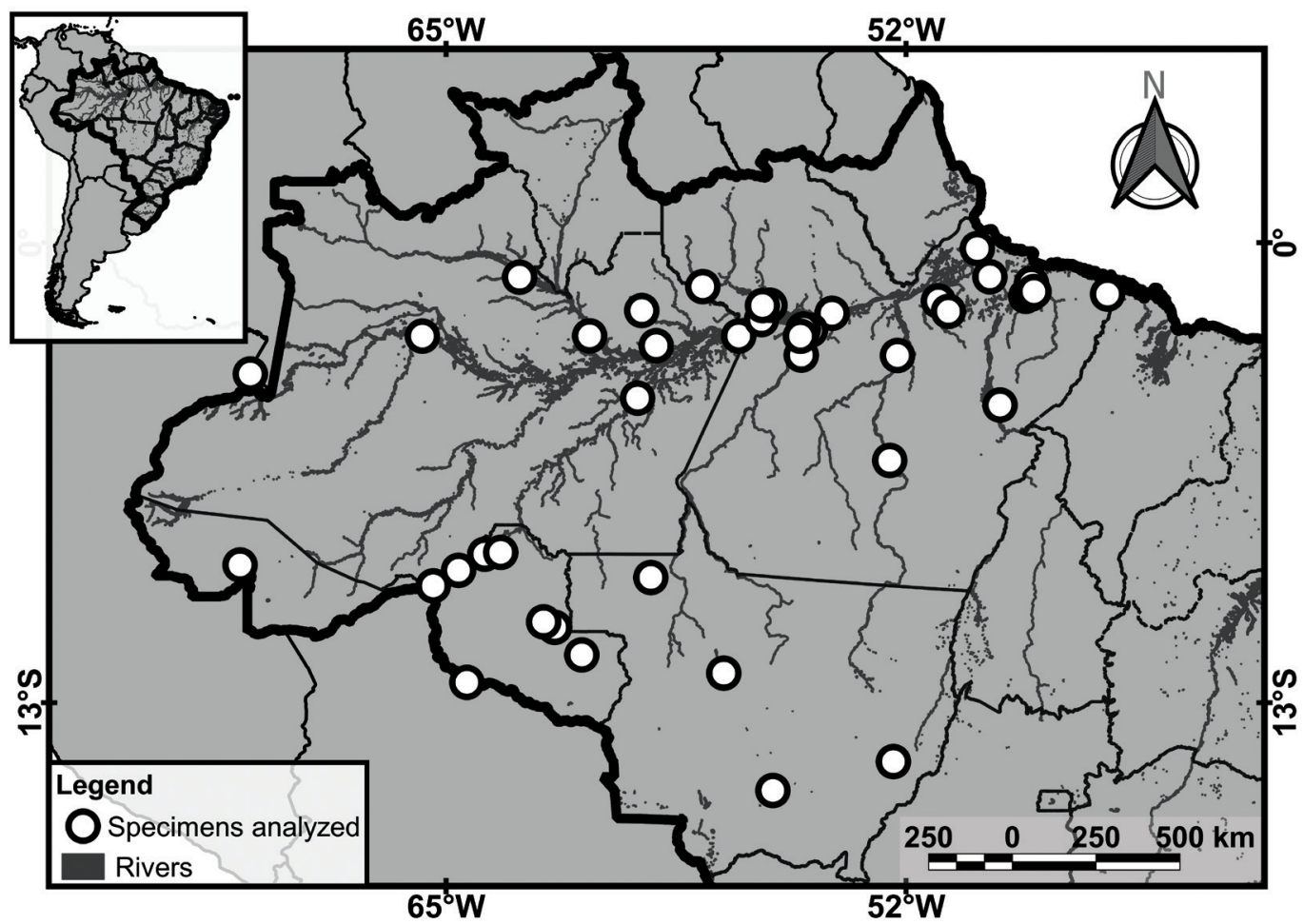

Figure 1. Geographic distribution of the Helicops polylepis specimens analyzed for sexual dimorphism (black circles). 
digital calipers (accuracy $0.01 \mathrm{~mm}$ ) to measure all variables, except SVL and TL, which were measured with a ruler to the nearest millimeter.

Sex of the specimens was determined by direct examination of the gonads. Males with convoluted deferent ducts were considered mature (Shine 1988), as were females with follicles $\geq 5 \mathrm{~mm}$ (Shine 1988). The smallest mature male measured $328 \mathrm{~mm}$ SVL and the smallest mature female $486 \mathrm{~mm}$ SVL. Based on this criterion, the number of adult males in our sample was 66, and adult females were 32 .

\section{Data Analysis}

We tested sexual dimorphism based only on sexually mature specimens, except for the number of ventral and subcaudal scales, which were measured for all specimens. To reduce the effects of size on the morphometric variables, we transformed each variable using the formula $\mathrm{Z}=\mathrm{Y}_{\mathrm{i}} \quad\left(\mathrm{SVL}_{0} / \mathrm{SVL}_{\mathrm{i}}\right)^{\mathrm{b}}$, where $\mathrm{Z}$ represents transformed value of the variable $\mathrm{Y}$ (variable affected by SVL), $Y_{i}$ is the individual value of the variable, $\mathrm{SVL}_{0}$ is the mean of the $\mathrm{SVL}, \mathrm{SVL}_{\mathrm{i}}$ is the individual value of the SVL, and $b$ represents the slope of the linear regression between $\log Y$ and $\log S V L$ (Lleonart et al. 2000). We verified the effectiveness of canceling the size effect after the transformations of the variables the analysis (Student's t-test) of the slope resulting from the regression of the SVL $\log _{10}$-transformed by the variables transformed by the formula presented above (Villamil et al. 2017). All transformed variables were not correlated with SVL $(p>0.05)$ and the slope of linear regression between these variables was statistically indistinguishable from zero.

We used ANOVA or Wilcoxon MannWhitney models to test sexual dimorphism in SVL (original data), TL (transformed as above), and number of ventral and subcaudal scales. Assumptions of normality and homoscedasticity were evaluated using Kolmogorov-Smirnov's and Levene's tests, respectively (Zar 2010). We assessed variation in body shape and the contribution of each morphometric variable to the overall sexual dimorphism using Principal Component Analysis (PCA). We excluded SVL and TL from the PCA. TL was removed because of the large number of specimens with mutilated tails ( $N=29,30 \%$ of the adult specimens). We also removed specimens with missing data from the sample, because it is not possible to calculate pairwise Euclidean distances on incomplete datasets (final sample $=63$ males and 30 females). The statistical support for the PCA was performed with an analysis of variance (ANOVA) using the scores of the first principal component of each sex.

We performed the univariate analysis using R 3.3.3 (R Development Core Team 2011) and the multivariate analysis using PAST 3.07 (Hammer et al. 2001). We assumed $\alpha=0.05$ to decide by accepting or rejecting null hypotheses for all tests.

\section{Results}

Descriptive statistics of morphometric and meristic variables are shown in Table 1 . The first principle component captured $65 \%$ of the variation observed in the PCA, and the second component captured 24\% (accumulated variance $=89 \%$ ) (Table 2). The transformed variables with the greatest contributions to component 1 and component 2 were HL and HW (Table 2). The two-dimensional projection of the first two principle components showed levels of overlap between sexes (Figure 2A); however, significant differences in component 1 scores between males and females of $H$. polylepis were observed (ANOVA: $\mathrm{F}_{1,91}=26.47 ; p=0.0001$; Figure 2B).

In the univariate analysis, significant differences were observed between the sexes for all variables tested (Table 1). Males showed higher values than females for subcaudal scales and TL, and females showed higher values for ventral scales, SVL, EMD, SL, HL, HW, and HH (Figure 3). 

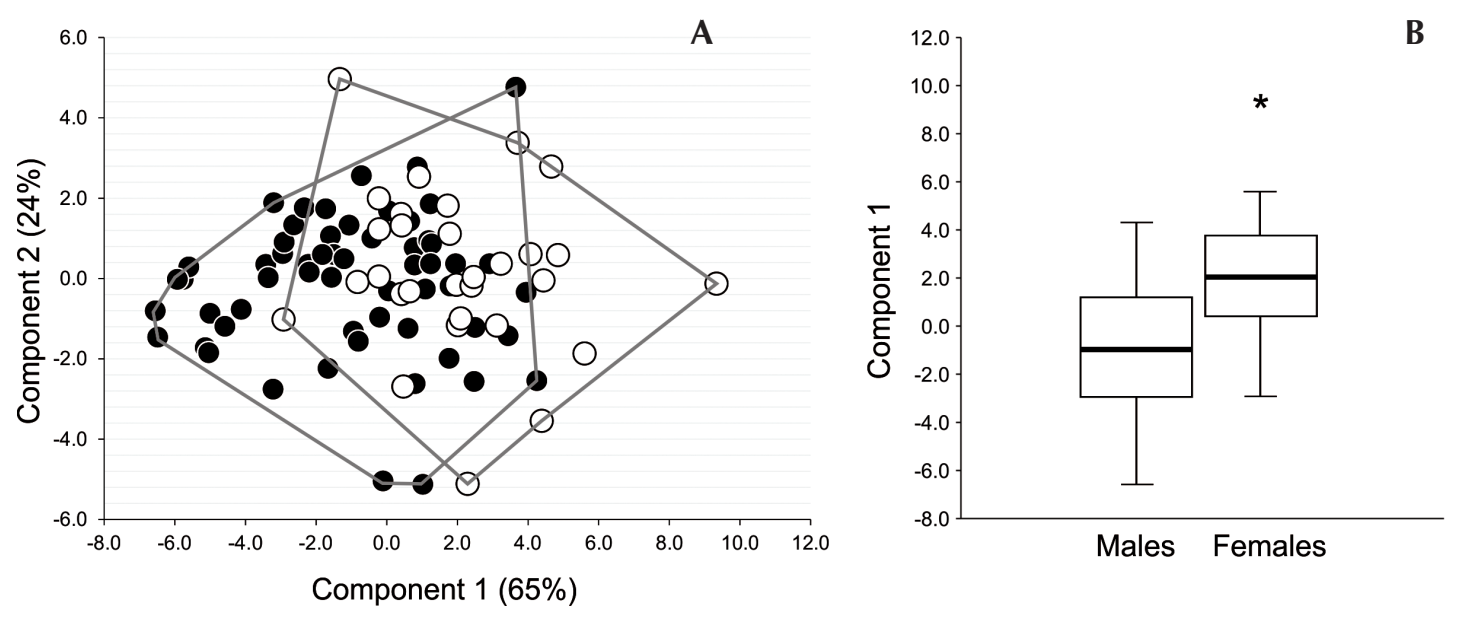

Figure 2. (A) Two-dimensional projection on morphometric variables of Helicops polylepis represented by two principal components from a PCA (black circles = males; white circles = females). (B) Males and females principal component 1 scores. Boxplot shows mean (solid bar), interquartile range (box) and minimum and maximum values (solid terminal bars). Asterisks represent outliers.

\section{Discussion}

We found that females of Helicops polylepis have larger body size than males, consistent with most viviparous snakes (Fitch 1981, Shine 1994). The same pattern has been found for two congeners: $H$. infrataeniatus (Aguiar and DiBernardo 2005) and H. leopardinus (Ávila et al. 2006). According to Shine (1978), females have larger body sizes than males in nearly $60 \%$ of snake species, probably due to selection for increased fertility, enabling larger females to produce and store greater numbers of eggs or embryos (Darwin 1981, Shine 1994, Olsson et al. 2002, Pizzatto and Marques 2006). Furthermore, female snakes often delay sexual maturity to maximize fecundity and reproductive success mediated by increased body fat accumulation (Brown and Weatherhead 1999, King 1999). In the analyzed sample, the smallest mature female of $H$. polylepis (SVL $486 \mathrm{~mm}$ ) was $158 \mathrm{~mm}$ longer than the smallest mature male (SVL $328 \mathrm{~mm}$ ), corroborating the hypothesis of late maturity for females.
Sexual dimorphism is a consequence of several forces, such as fertility selection and sexual selection, which act on the sexes and favor larger size in many organisms (Blanckenhorn 2005). The small slender body size of $H$. polylepis males may indicate the absence of ritual fighting between males. Sexual selection favors maturation earlier and at a smaller size in males than in females, thereby allowing greater likelihood of finding mature females (Pizzatto and Marques 2006). Early maturation may increase reproductive production due to the development of chemosensory senses, high mobility, and reduced costs of mating dispersal and courtship of females (Madsen and Shine 1994). Additionally, sex-related body size in aquatic snakes may affect the ability to follow reproductive chemical clues, because larger females may produce greater amounts of pheromone, which reduces the effects of dilution in aquatic habitats (Shine 1993). This is apparently a phylogenetically conservative character, because no species in which males are larger than females has been found in Hydropsini snakes. 


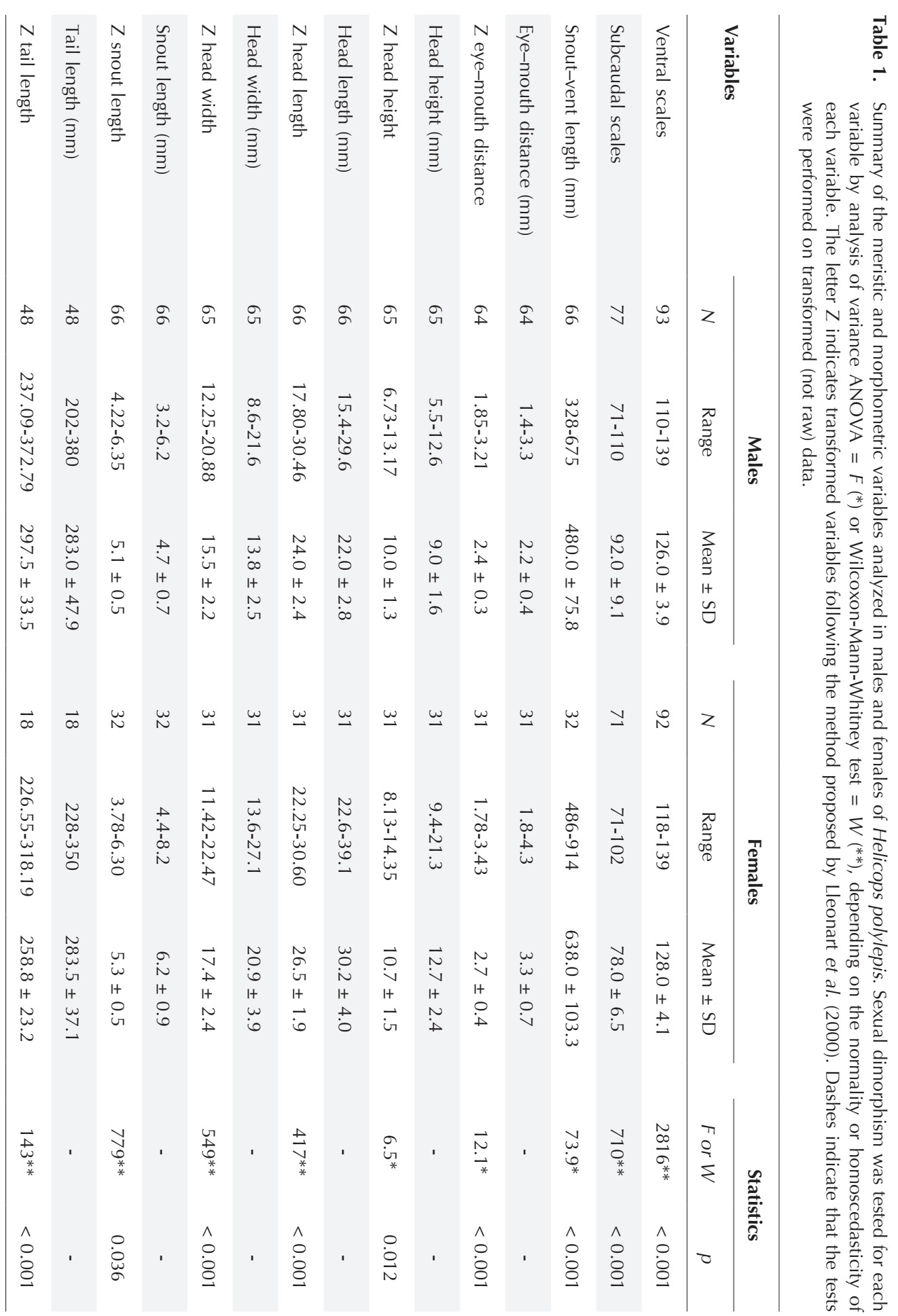


A
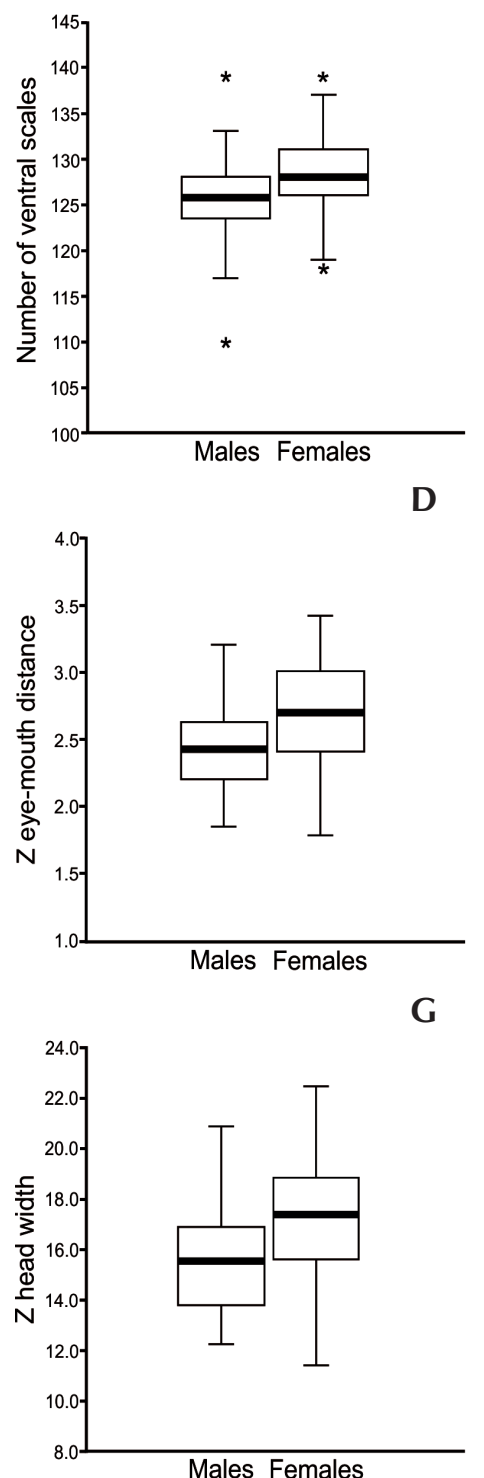

B
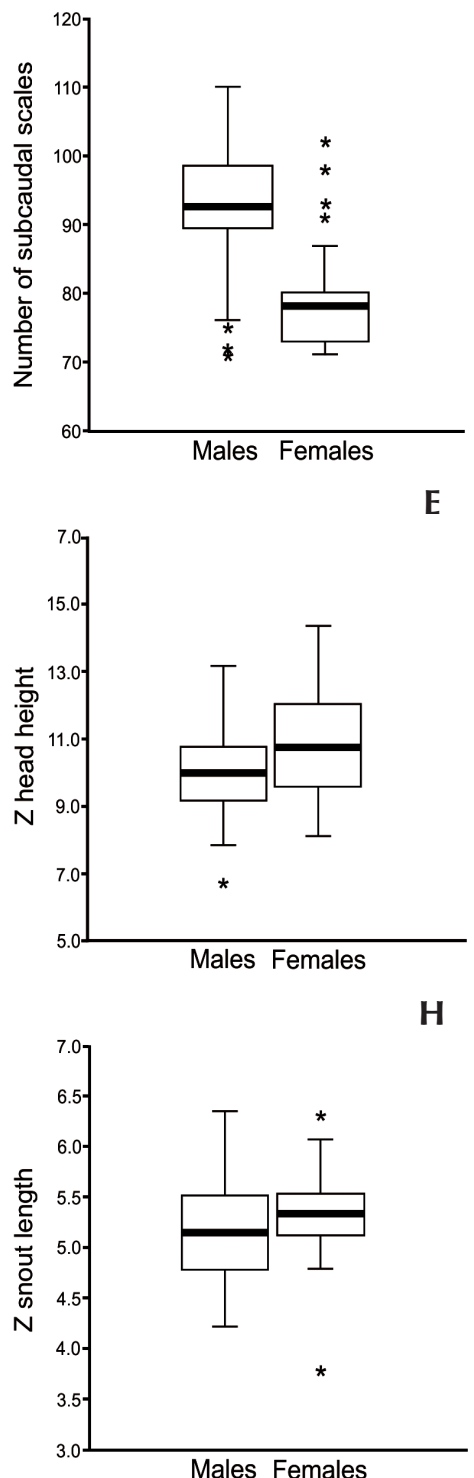
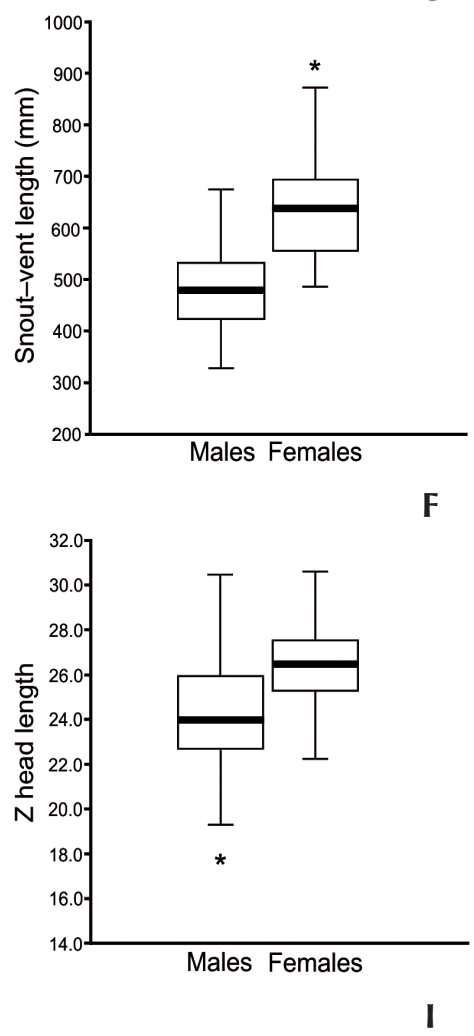

C

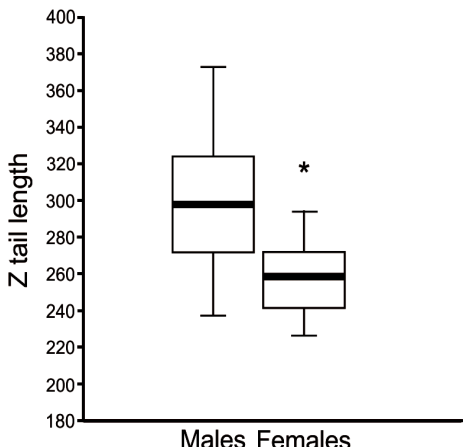

Figure 3. Comparison of meristic and morphometric variables between males and females of Helicops polylepis. Boxplot shows mean (solid bar), interquartile range (box) and minimum and maximum values (solid terminal bars). Asterisks represent outliers. (A) Number of ventral scales, (B) number of subcaudal scales, (C) snoutvent length, (D) Z eye-mouth distance, (E) Z head height, (F) head length, (G) Z head width, (H) Z snout length, (I) Z tail length. 
Table 2. Contribution of each variable to the principal components 1 and 2 with the main morphometric characters (bold) that contributed to the variation observed in the Principal Component Analysis.

\begin{tabular}{lcc}
\hline Variables & Component 1 & Component 2 \\
\hline Eye-mouth distance & 0.6394 & 0.1204 \\
Head height & 0.5066 & 0.3448 \\
Head length & $\mathbf{0 . 8 7 5 6}$ & $\mathbf{0 . 4 5 1 7}$ \\
Head width & $\mathbf{0 . 8 2 4 0}$ & $\mathbf{- 0 . 5 6 6 2}$ \\
Snout length & 0.4546 & 0.1947 \\
Eigenvalue & 8.99661 & 3.27995 \\
\% variance & 65 & 24 \\
\hline
\end{tabular}

The levels of sexual dimorphism we found for tail length is consistent with literature for many snake species (Shine et al. 1999), including representatives of the genus Helicops (Aguiar and Di-Bernardo 2005, Santos-Jr. and Ribeiro 2005, Ávila et al. 2006). Longer tails in male snakes may be related to the presence of the hemipenis and the associated retractile muscles located at the base of the tail (King et al. 1999). Sexual dimorphism in tail length may also be related to reproductive efficiency, since males with larger tails have advantages over smaller tailed males in ritualized mating displays (Pizzatto et al. 2007). We do not have data to test this hypothesis for $H$. polylepis, and ritual combat is very unlikely. We also found sexual dimorphism in head size, which may allow predation on prey of different sizes (Camilleri and Shine 1990) and provide more energy for reproductive investment (Shine 1994). This is not necessarily strictly based on food limitation or between-sex competition but may be related to independent adaptation of each sex to increase the efficiency of foraging and habitat use (Shine 1986). Sexual dimorphism in head size influences the shape and size of structures directly associated with feeding, which are usually larger in the sex with the larger head (Camilleri and Shine 1990).
The levels of sexual dimorphism detected in this study suggest sexual selection as a major process causing morphological divergence between sexes. This finding is supported by the fact that sexual dimorphism has been found in H. polylepis neonates (Santos-Jr. and Ribeiro 2005), which shows that morphological differences between sexes are more likely to be innate than acquired over life by environmental pressure. However, additional data on growth rates associated with prey availability and female size-related offspring size are necessary to refine our analyzes and test specific hypotheses about the ecological and evolutionary bases of sexual dimorphism in $H$. polylepis.

\section{Acknowledgments}

We thank all the curators who allowed us to visit their collections and to access and borrow specimens: Martha Calderón (ICN), Andrés R. Acosta-Galvis (IAvH), Ana Prudente (MPEG), Paulo Passos (MNRJ), Felipe Franco Curcio (UFMT), Giuseppe Puorto (IBSP), Moisés Barbosa (UFAC), Fernanda Werneck (INPAAM), Hipócrates Chalkidis (FIT) and Emil Hernández (UFPA-Altamira). Adrian Barnett helped with the English. We thank Jaime Bertoluci, Ross MacCulloch, and the anonymous reviewers for comments and suggestions. I.C.M.C thanks Coordenação de Aperfeiçoamento de Pessoal de Nível Superior (CAPES) for the master's study grant. CAPES provided a postdoctoral fellowship to RF (PNPD).

\section{References}

Aguiar, L. F. S. and M. Di-Bernardo. 2005. Reproduction of the water snake Helicops infrataeniatus (Colubridae) in Southern Brazil. Amphibia-Reptilia 26: 527-533.

Almeida-Santos, S. M. and M. G. Salomão. 2002. Reproduction in neotropical pitvipers, with emphasis on species of the genus Bothrops. Pp. 445-462 in G. W. Schuett (ed.), Biology of the Vipers. Eagle Mountain. Eagle Mountain Publishing. 
Anderson, R. A. and L. J. Vitt. 1990. Sexual selection versus alternative causes of sexual dimorphism in teiid lizards. Oecologia 84: 145-157.

Andersson, M. 1994. Sexual Selection. Princeton. Princeton University Press. 624 pp.

Ávila, R. W., V. L. Ferreira, and J. A. O. Arruda. 2006. Natural history of the South American Water Snake Helicops leopardinus (Colubridae: Hydropsini) in the Pantanal, Central Brazil. Journal of Herpetology 40: 274-279.

Avolio, C., R. Shine, and A. Pile. 2006. Sexual dimorphism in scale rugosity in sea snakes (Hydrophiidae). Biological Journal of the Linnean Society 89: 343-354.

Balestrin, R. L. and M. Di-Bernardo. 2005. Reproductive biology of Atractus reticulatus Boulenger, 1885 (Serpentes, Colubridae) in southern Brazil. Herpetological Journal 15: 195-199.

Blanckenhorn, W. U. 2005. Behavioral causes and consequences of sexual size dimorphism. Ethology 111: 977-1016.

Bonnet, X., R. Shine, G. Naulleau, and M. Vallas-Vacher. 1998. Sexual dimorphism in snakes: different reproductive roles favour different body plans. Proceedings of the Royal Society B: Biological Sciences 265: 179-183.

Brown, G. P. and P. J. Weatherhead. 1999. Female distribution affects mate searching and sexual selection in male northern water snakes (Nerodia sipedon). Behavioral Ecology and Sociobiology 47: 9-16.

Camilleri, C. and R. Shine. 1990. Sexual dimorphism and dietary divergence: differences in trophic morphology between male and female snakes. Copeia 1990: 649658.

Crews, D. 1984. Gamete production, sex hormone secretion, and mating behavior uncoupled. Hormones and Behavior 18: 22-28.

Darwin, C. R. 1981. The Descent of Man, and Selection in Relation to Sex. Princeton. Princeton University Press. 960 pp.

Dowling, H. G. 1951. A proposed standard system of counting ventrals in snakes. British Herpetological Society 1: 97-99.

Fitch, H. S. 1981. Sexual size differences in reptiles. Miscellaneous Publications of the Museum of Natural History, University of Kansas 70: 1-72.

Furtado, M. F. D., S. R. Travaglia-Cardoso, and M. M. T. Rocha. 2006. Sexual dimorphism in venom of Bothrops jararaca (Serpentes: Viperidae). Toxicon 48: 401-410.
Giraudo, A. R., V. Arzamendia, G. P. Bellini, C. A. Bessa, and M. B. Costanzo. 2014. Ecología de una gran serpiente sudamericana, Hydrodynastes gigas (Serpentes: Dipsadidae). Revista Mexicana de Biodiversidad 85: 1206-1216.

Hammer, O., H. Dat, and P. D. Ryan. 2001. PAST: Paleontological statistic software package for education and data analysis. Version 3.26. URL: http:// palaeoelectronica.org/2001_1/past/issue1_01.htm.

King, R. B. 1989. Sexual dimorphism in snake tail length: sexual selection, natural selection, or morphological constraint? Biological Journal of the Linnean Society 38: 133-154.

King, R. B., T. D. Bittner, A. Queral-Regil, and J. H. Cline. 1999. Sexual dimorphism in neonate and adult snakes. Journal of Zoology 247: 19-28.

Kissner, K. J., M. R Forbes, and D. M. Secoy. 1998. Sexual dimorphism in size of cloacal glands of garter snake, Thamnophis radix haydeni. Journal of Herpetology 32: $268-270$.

Lleonart, J., J. Salat, and G. J. Torres. Removing allometric effects of body size in morphological analysis. Journal of Theoretical Biology 205: 85-93.

Luiselli, L., F. M. Angelici, and G. C. Akani. 2002. Comparative feeding strategies and dietary plasticity of the sympatric cobras Naja melanoleuca and Naja nigricollis in three diverging Afrotropical habitats. Canadian Journal of Zoology 80: 55-63.

Madsen, T. and R. Shine. 1994. Costs of reproduction influence the evolution of sexual size dimorphism in snakes. Evolution 48: 1389-1397.

Marques, O. A. V., S. M. Almeida-Santos, M. Rodrigues, and R. Camargo. 2009. Mating and reproductive cycle in the Neotropical colubrid snake Chironius bicarinatus. South American Journal of Herpetology 4: 76-80.

Mesquita, P. C. M. D., D. M. Borges-Nojosa, and C. H. Bezerra. 2010. Dimorfismo sexual na "cobra-cipó" Oxybelis aeneus (Serpentes, Colubridae) no estado do Ceará, Brasil. Biotemas 23: 65-69.

Olsson, M., R. Shine, E. Wapstra, B. Ujvari, and T. Madsen. 2002. Sexual dimorphism in lizard body shape: The roles of sexual selection and fecundity selection. Evolution 56: 1538-1542.

Peters, J. A. 1964. Dictionary of Herpetology. New York, Hafner. 393 pp.

Pizzatto, L. and O. A. V. Marques. 2006. Interpopulational variation in sexual dimorphism, reproductive output, and parasitism of Liophis miliaris (Colubridae) in the Atlantic forest of Brazil. Amphibia-Reptilia 27: 37-46. 
Pizzatto, L., O. A. V. Marques, and M. Martins. 2007. Ecomorphology of Boine snakes, with emphasis on South American forms. Pp. 35-48 in R. W. Henderson and R. Powell (eds.), Biology of the Boas and Pythons. Eagle Mountain. Eagle Mountain Publishing.

R Development Core Team. 2011. R: A language and environment for statistical computing. R Foundation for Statistical Computing, Vienna, Austria.

Santos-Jr., A. P. and F. R. Ribeiro. 2005. Dimorfismo sexual em uma prole da cobra-d'água Helicops polylepis Günther, 1861 (Serpentes: Colubridae) do oeste do estado do Pará, Brasil, com comentários sobre o período reprodutivo. Comunicações do Museu de Ciências e Tecnologia da PUCRS, Série Zoologia 18: 67-71.

Shetty, S. and R. Shine. 2002. Sexual divergence in diets and morphology in Fijian sea snakes Laticauda colubrina (Laticaudinae). Austral Ecology 27: 77-84.

Shine, R. 1978. Sexual size dimorphism and male combat in snakes. Oecologia 33: 269-277.

Shine, R. 1986. Sexual differences in morphology and niche utilization in an aquatic snake, Acrochordus arafurae. Oecologia 69: 260-267.

Shine, R. 1988. The evolution of large body size in females: a critique of Darwin "Fecundity advantage" model. American Naturalist 131: 124-131.

Shine, R. 1989. Ecological causes for the evolution of sexual dimorphism: a review of the evidence. Quarterly Review of Biology 64: 419-461.

Shine, R. 1991. Intersexual dietary divergence and the evolution of sexual dimorphism in snakes. American Naturalist 138: 103-122.

Shine, R. 1993. Sexual dimorphism in snakes. Pp. 49-86 in R. A. Seigel and J. T. Collins (eds.), Snakes: Ecology and Behavior. New York. McGraw-Hill.

Shine, R. 1994. Sexual dimorphism in snakes revised. Copeia 1994: 326-346.
Shine, R. and D. Crews. 1988. Why male garter snakes have small heads: the evolution and endocrine control of sexual dimorphism. Evolution 42: 1105-1110.

Shine, R., M. M. Olsson, I. T. Moore, M. P. Lemaster, and R. T. Mason. 1999. Why do male snakes have longer tails than females? Proceedings of the Royal Society B: Biological Sciences 266: 2147-2151.

Silva Jr., N. J. 1993. The snakes from Samuel Hydroelectric power plant and vicinity, Rondônia, Brazil. Herpetological Natural History 1: 37-86.

Teixeira, C. C., L. F. A. Montag, and M. C. Santos-Costa. 2017. Diet composition and foraging habitat use by three species of water snakes, Helicops Wagler, 1830 (Serpentes: Dipsadidae) in Eastern Brazilian Amazonia. Journal of Herpetology 51: 215-222.

Thorpe, R. S. 1989. Pattern and function of sexual dimorphism: a biometric study of character variation in the Grass Snake (Natrix natrix, Colubridae) due to sex and its interaction with geography. Copeia 1989: 5363.

Villamil, J., A. Camargo, and R. Maneyro. 2017. Morphological variation and sexual dimorphism in Liolaemus wiegmannii (Duméril \& Bibron, 1837) (Squamata: Liolaemidae) from Uruguay. Acta Herpetologica 12: 3-17.

Zaher, H., F. G. Grazziotin, J. E. Cadle, R. W. Murphy, J. C. Moura-Leite, and S. L. Bonatto. 2009. Molecular phylogeny of advanced snakes (Serpentes, Caenophidia) with an emphasis on South American Xenodontines: a revised classification and description of new taxa. Papéis Avulsos de Zoologia 49: 115-153.

Zar, J. H. 2010. Biostatistical Analysis. New Jersey. PrenticeHall. 960 pp.

Editor: Ross D. MacCulloch 
Appendix I. Specimens analyzed. We analyzed 186 specimens of Helicops polylepis from the following collections (acronyms are those used by the institutions): Centro de Estudos e Pesquisas Biológicas da Universidade Católica de Goiás, Goiânia, Brazil (CEPB), Instituto Butantan, São Paulo, Brazil (IBSP); Instituto Nacional de Pesquisas da Amazônia, Manaus, Brazil (INPA); Museu Paraense Emílio Goeldi, Belém, Brazil (MPEG); Universidade Federal do Mato Grosso, Cuiabá, Brazil (UFMT-R); Museu Nacional do Rio de Janeiro, Rio de Janeiro, Brazil (MNRJ); Laboratório de Zoologia de Altamira da Universidade Federal do Pará, Altamira, Brazil (LZATM), Universidade Federal do Oeste do Pará, Santarém, Brazil (UFOPA-H); Linha de Pesquisa em Herpetologia da Amazônia das Faculdades Integradas do Tapajós, Santarém, Brazil (LPHA); Universidade Nacional da Colômbia, Bogotá, Colombia (ICN), Instituto Alexander Von Humboldt, Villa de Leyva, Boyacá, Colombia (IAvH-R).

BRAZIL: ACRE: CCBN 74, CCBN 75, CCBN 273, CCBN 352, MPEG 20516. MANAUS, Amazonas, Alto Rio Solimões: MNRJ 641. Barcelos: INPA-H 25360. Borba: MNRJ 1559. Lindóia: MPEG 23514, MPEG 23513. Parintins: MNRJ 13333. Novo Airão: IBSP 80595, IBSP 80596, IBSP 80597, IBSP 80.598, IBSP 80599, IBSP 80600, IBSP 80601, IBSP 80602, IBSP 80603, IBSP 80604, IBSP 80605, IBSP 80619, IBSP 80620, IBSP 80621, IBSP 80622, IBSP 80623, IBSP 80624, IBSP 80625, IBSP 80626, IBSP 80627, IBSP 80628, IBSP 80629, IBSP 80630, IBSP 80631, IBSP 80632, IBSP 80633, IBSP 80634, MPEG 24374. Usina Hidrelétrica de Balbina: CEPB-565. MATO GROSSO: UFMT-R 215. Chapada dos Guimarães: UFMT-R 506, UFMT-R 507, UFMT-R 1218, UFMT-R 1219. Colniza, Estação Ecológica do Rio Roosevelt: UFMT-R 6683; UFMT-R7796. Príncipe da Beira: UFMT-R 9285, UFMT-R 9292. Nova Xavantina: UFMT-R 7768. PARÁ, Altamira: LZATM 61, LZATM 121, LZATM 860. Baia do Souzel - Baixo Rio Xingu: MPEG 16715. Barcarena: MPEG 17680, MPEG 17729, MPEG 20480, MPEG 21856. Belém: MPEG 828, MPEG 16258, MPEG 18523, MPEG 18572, MPEG 22295. Belterra, Comunidade de Porto Novo: IBSP 86122, LPHA 360, LPHA 641, LPHA 1477, LPHA 1556, LPHA 1557, LPHA 2149, LPHA 2150, LPHA 2172, LPHA 2173, LPHA 2174, LPHA 2251, LPHA 2436, LPHA 2438, LPHA 2439, LPHA 2440, LPHA 2441, LPHA 2444, LPHA 2445, LPHA 2447 LPHA 2448, LPHA 2449, LPHA 2450, LPHA 2451, LPHA 2452, LPHA 2453, LPHA 2454, LPHA 2457, LPHA 2459, LPHA 2437, LPHA 2446, LPHA 2455, LPHA 2456, LPHA 2458, LPHA 2584, LPHA 2587, LPHA 2588, LPHA 2589, LPHA 2591, LPHA 2592, LPHA 2594, LPHA 2595, LPHA 2596, LPHA 2597, LPHA 2598, LPHA 2599, LPHA 2610, LPHA 2611 LPHA 2612 LPHA 2613, LPHA 2614, LPHA 2615, LPHA 2618, UFOPA-H 141, UFOPA-H 142, UFOPA-H 143, UFOPA-H 144,_UFOPA-H 859, UFOPA-H 861, UFOPA-H 872, UFOPA-H 873, UFOPA-H 874, UFOPA-H 875. Chaves: MPEG 12427, MPEG 14793, MPEG 21118. Colônia Nova: MPEG 1851, MPEG 2943, MPEG 8604, MPEG 8616, MPEG 15082, MPEG 15104, MPEG 15108, MPEG 20952, MPEG 21188. Faro: MPEG 18160 MPEG 21179. Ilha de Mosqueiro: MPEG 1215, MPEG 16440. Ilha de Marajó: MPEG 8871. Jacundá: MPEG 18353. Juruti: MPEG 21189, MPEG 21190, MPEG 22671, MPEG 23250, MPEG 23284, MPEG 24210. Melgaço: MPEG 15078, MPEG 18472, MPEG 18535, MPEG 21855, MPEG 21857, MPEG 22140, MPEG 23249. Monte Alegre: MPEG 21511, UFOPA-H 387. Oriximiná: MNRJ 7789, MNRJ 17940. Oriximiná, Lago de Sapuacá: UFMT-R 9732, UFMT-R 10241 UFMT-R 10246. Portel: MPEG 15105, MPEG 23248. Santarém: UFOPA-H 387, UFOPA-H 1036, LPHA 2586, LPHA 2590. RONDÔNIA, Porto Velho: INPA-H 10330, INPA-H 12427, INPA-H 14793, MPEG 26058. Distrito de Abunã: MPEG 16754 MPEG 16337, MPEG 21125. Ji-Paraná MPEG 18359. Ouro Preto do Oeste: MNRJ 9034. Pimenta Bueno, UFMT-R 8194. Usina Hidrelétrica Jirau: MPEG 22672. Usina Hidrelétrica de Samuel: CEPB-981.

COLOMBIA: Letícia: ICN-R 8524, ICN-R 8579, IAvH-R 2267, IAvH-R 2296, IAvH-R 2297, IAvH-R 3079. 